\title{
Presidensialisme Dan Problematika Mekanisme Impeachment Presiden Dan/Atau Wakil Presiden Berdasarkan UUD 1945 Pasca Perubahan (Perspektif Pergulatan Hukum Dan Politik)
}

\section{Gusti Ngurah Santika}

FKIP, Universitas Dwijendra Denpasar

\section{A R T I C L E I N F O Article history: Received 9 Juni 2019 Accepted 29Juni 2019 Available online 30 Juni 2019}

Kata Kunci: UUD 1945; Impeachment; Hukum dan Politik

Keywords: UUD 1945, Impeachment; Law and Politic

\begin{abstract}
A B S T R A K
UUD 1945 pasca perubahan telah memformulasikan mekanisme pemberhentian atau pemakzulan (impeachment) Presiden dan/atau Wakil Presiden secara lebih jelas dan tegas. Perubahan ini bermaksud meneguhkan dan memantapkan, bukan hanya sistem pemerintahan tetapi juga prinsipprinsip negara hukum yang dipraktikan Indonesia. Dengan demikian, Indonesia melalui Perubahan UUD 1945 ingin mengimplemntasikan kedaulatan hukum atas politik dalam pemberhentian Presiden dan/atau Wakil Presiden. Oleh karena itulah, mengapa UUD 1945 pasca perubahan melibatkan Mahkamah Konstitusi melalui forum previlegiatum dalam mekanisme pemberhentian Presiden dan/atau Wakil Presiden. Tetapi, realitasnya putusan Mahkamah Konstitusi tidaklah final dan mengikat MPR untuk mengikuti putusan tersebut, sehingga MPR secara politik bisa saja menganulir putusan Mahkamah Konstitusi. Berdasarkan latar belakang di atas, maka akan diteliti Pergulatan Hukum dan Politik Dalam Mekanisme Impeachment Presiden dan/atau Wakil Presiden Berdasarkan UUD 1945 Pasca Perubahan. Pengumpulan data dilakukan dengan metode observasi, literatur atau kepustakaan, dan dokumentasi dimana hasil pengolahan data disajikan dengan deskriptif analisis yang disusun secara sistematis. Hasil penelitian ini menunjukan, bahwa sistem konstitusi Indonesia memposisikan politik lebih tinggi (superior) bila dibandingkan dengan hukum, terutamanya dalam mekanisme impeachment Presiden dan/Wakil Presiden.
\end{abstract}

\section{A B S T R A C T}

The post-amendment of our State's Constitution, UUD 1945 has formulated the mechanism for the impeachment of the President and / or Vice-President more clearly and explicitly. This change intends to strengthen, and bring better things, not only for the system of government but also for the principles of the rule of law practiced by Indonesia. Therefore, Indonesia had through the Amendment to the 1945 Constitution wants to implement legal sovereignty over politics in the dismissal of the President and / or Vice President. Therefore, why the 1945 Constitution after the changes involved the Constitutional Court through the forum previlegiatum in the mechanism of dismissal of the President and / or Vice President. However, in reality the Constitutional Court's decision was not final and binding on the MPR to follow the decision, so that the MPR could politically annull the decision of the Constitutional Court. Based on the background above, the Law and Political Struggle in the Impeachment Mechanism of the President and / or Vice President will be examined based on the Post-Amendment of the 1945 Constitution. Data collection is done by the method of observation, literature, and documentating where the results of data processing are presented with descriptive analysis that is arranged systematically. The results of this study indicate that the Indonesian constitutional system positions politics superior (superior) when compared to the law, especially in the impeachment mechanism of the President and / Vice President.

\footnotetext{
* Corresponding author.

Email : ngurahsantika88@gmail.com
} 


\section{Pendahuluan}

Apabila ditinjau dari segi hukum maupun politik, maka di negara manapun kedudukan Pesiden sangatlah vital dalam menentukan perjalanan bangsa ke depan, termasuk kehidupan ketatanegaraannya (Suwoto. 1997: 53). Terlebih lagi di negara yang muatan konstitusinya secara formal menganut dan juga mempraktikan sistem pemerintahan presidensial. Berdasarkan konstitusi Indonesia, yaitu UUD Tahun 1945, baik sebelum maupun sesudah perubahan menyatakan, bahwa sistem pemerintahan yang dianut oleh Indonesia secara konstitusional lebih menonjolkan sistem presidensial ketimbang sistem parlementer. Hal tersebut sesuai dengan ciri dari pemerintahan presidensial adalah masa jabatan presiden yang ditentukan oleh UUD (Lijphart, Arend, 1994: 5). Jadi, dengan masa jabatan seorang presiden yang pasti (fixed term) yang diatur dalam konstitusi, maka posisi seorang presiden bisa dikatakan kokoh atau kuat (strong executive) (Fatkhurohman dan Sjuhad. 2010: 166). Dengan demikian, kedudukan presiden dalam sistem pemerintahan presidensial sangat kuat dibandingkan kedudukan perdana menteri dalam sistem pemerintahan parlementer, dan merupakan hal wajar karena sistem presidensial dimaksudkan untuk menciptakan pemerintahan yang relatif stabil dalam jangka waktu tertentu (fix term office period) (Zoelva, 2011: 58).

Menilik Indonesia dalam praktik ketatanegaraannya yang lampau, bahwa fenomena yang berjalan selama empat dekade terakhir ini menunjukkan kecenderungan pengaturan sistem bernegara yang lebih berat ke lembaga eksekutif (executive heavy). Posisi Presiden sebagai kepala negara sekaligus sebagai kepala pemerintahan yang tidak jelas batasan wewenangnya dapat berkembang ke arah yang negatif berupa penyalahgunaan wewenang (Ni'mah, Muni' Datun, 2012: 48).

Sebelum perubahan, UUD 1945 memberikan kekuasaan politik yang besar kepada Presiden (Ambardi, 2009: 72) dalam menyelenggarakan fungsi dan tugas pemerintahan. Pemberian kewenangan tersebut rupanya tanpa diibarengi dengan batasan-batasan konstitusional yang memadai terhadap penggunaannya. Implikasinya wewenang tersebut menjadi meluas di berbagai bidang dan tidak lagi dijalankan sesuai dengan relnya. Zaman pemerintahan Presiden Soekarno dan Soeharto telah cukup membuktikan bagaimana UUD 1945 membuka peluang besar terjadinya penyelewengan/penyalahgunaan terhadap kekuasaan (abuse of power).

Ditambah lagi dengan kenyataan bahwa UUD 1945 sebelum perubahan, tidak mengatur secara jelas dan tegas pemberhentian Presiden dan/atau Wakil Presiden dalam masa jabatannya baik mengenai alasan maupun mekanismenya. Pasal 8 UUD 1945 sebelum perubahan menyatakan, bahwa "Jika Presiden mangkat, berhenti atau tidak dapat melakukan kewajibannya dalam masa jabatannya, ia diganti oleh Wakil Presiden sampai habis masa jabatannya". Dari ketentuan tersebut, kata "berhenti" secara implisit memberikan kemungkinan bagi seorang Presiden diberhentikan ditengah jabatannya, yaitu bisa berarti berhenti karena mengundurkan diri maupun berhenti karena diberhentikan. Dalam UUD 1945 sebelum perubahan, mekanisme impeachment/pemberhentian terhadap Presiden dan/atau Wakil Presiden tidak diatur secara detail, tegas, dan jelas. Kewenangan prerogatif atau mutlak untuk memberhentikan Presiden apabila tebukti dengan sungguh-sungguh melanggar haluan negara (GBHN) adalah MPR.

Proses pemberhentian Presiden Republik Indonesia, mulai sebelum Perubahan UUD 1945 sampai dengan setelah Perubahan UUD 1945 keempat, sesungguhnya bukan sesuatu hal mudah. Pada masa UUD 1945 sebelum diubah, yang dapat memberhentikan Presiden, adalah MPR yang susunannya terdiri dari anggota DPR, dan utusan golongan, serta utusan daerah. Pemberhentian Presiden, dapat dilakukan melalui mekanisme Sidang Istimewa MPR, dengan alasan, bahwa Presiden telah melakukan kejahatan, pengkhianatan terhadap negara, serta tidak mampu lagi menjalankan fungsi jabatannya. Namun, pasca Perubahan UUD 1945 mekanisme pemberhentian Presiden di Indonesia, justru jauh lebih rumit daripada sebelumnya. Mulai dari lembaga yang terlibat maupun proses yang harus dilalui berbeda sekali dengan sebelum UUD 1945 diubah. Dan bahwa dalam keadaan normal, sangatlah sulit untuk menjatuhkan atau impeachment Presiden dan/atau Wakil Presiden. Bahwa memang benar prosedur pemberhentian Presiden 
dan/atau Wakil Presiden dalam masa jabatannya telah disediakan UUD 1945. Hanya saja untuk dapat menempuhnya memerlukan proses perjalanan politik dan hukum yang cukup panjang serta berliku-liku tajam. Baik dilihat dari sisi keterlibatan organ negara dan pengaturan mekanisme impeachment dalam UUD 1945 maka masih terdapat ruang pergulatn antara politik dengan hukum. Mengingat letak kewenangan pemberhentian Presiden dan/atau Wakil Presiden berada pada MPR tapi melibatkan MK di dalamnya.

Berdasarkan deskripsi singkat di atas peneliti tertarik untuk mengkaji lebih dalam lagi mengenai Presidensialisme dan Problematika Mekanisme Impeachment Presiden dan/atau Wakil Presiden Berdasarkan Perubahan UUD 1945 (Perspektif Pergulatan Politik dan Hukum). Berdasarkan uraian latar belakang tersebut di atas, maka rumusan permasalahan dalam penelitian ini adalah bagaimana hubungan antara presidensialisme denggan mekanisme impeachment Presiden dan/atau Wakil Presiden berdasarkan Perubahan UUD 1945? Dan problematika apa saja yang dijumpai dalam mekanisme impeachment Presiden dan/atau Wakil Presiden berdasarkan Perubahan UUD 1945? Apakah mekanisme impeachment Presiden dan/atau Wakil Presiden sudah sesuai dengan prinsip negara hukum, yang meletakan hukum lebih tinggi dari politik? Berkaitan dengan uraian di atas, maka adapun tujuan yang ingin dicapai dalam penelitian ini adalah sebagai berikut: Untuk hubungan antara presidensialisme denggan mekanisme impeachment Presiden dan/atau Wakil Presiden berdasarkan Perubahan UUD 1945. Untuk mengetahui problematika mekanisme impeachment Presiden dan/atau Wakil Presiden berdasarkan Perubahan UUD 1945. Untuk mengetahui problematika apa saja yang dijumpai dalam mekanisme impeachment Presiden dan/atau Wakil Presiden berdasarkan Perubahan UUD 1945. Untuk mengetahui mekanisme impeachment Presiden dan/atau Wakil Presiden apakah sudah sesuai dengan prinsip negara hukum, yang memposisikan hukum lebih tinggi dari politik.

Menurut Jimly Asshiddiqie, (2007: 600), bahwa mekanisme pemberhentian presiden dikenal dalam praktik ketatanegaraan di berbagai negara, secara istilah proses ketatanegaraan ini disebut juga sebagai pemakzulan, namun banyak nomenklatur dan pemberitaan yang menyebutnya sebagai impeachment. Impeachment, adalah kata yang biasa ditujukan kepada seorang kepala negara, dalam hal ini presiden. Kata impeachment sendiri dalam bahasa Indonesia dapat kita alih bahasakan sebagai pemakzulan, dakwaan atau tuduhan Impeachment, berasal dari kata aktif "to impeach" yang artinya adalah meminta pertanggungjawaban. Jika tuntutannya terbukti maka konsekuensinya adalah "removal from office" atau pemberhentian dari jabatan. Dalam teori hukum tata negara (constitutional law theory), pemberhentian presiden di tengah masa jabatannya disebut impeachment (pemakzulan) yang secara hukum merupakan a legal process of removing an undersirable person from public office (Isra, 2010 ; 63) Dalam artian bahwa impeachment sendiri bukanlah hukumannya, namun bagian atau tahapan dari sebuah proses yang bersifat penuntutan atas dasar pelanggaran hukum yang dilakukan oleh presiden. Dengan demikian, bahwa persoalan impeachment atau yang secara etimologis berarti pendakwaan, atau tuduhan atau panggilan untuk melakukan pertanggung jawaban (Sapuan, 2010: 56).

Dalam hubungannya dengan kedudukan kepala negara atau kepala pemerintahan, impeachment berarti pemanggilan atau pendakwaan untuk meminta pertanggungjawaban atas persangkaan pelanggaran hukum yang dilakukannya dalam masa jabatannya. Dengan demikian penggunaan pranata impeachment dalam sistem hukum yang sering digunakan terutama menurut hukum tata negara lebih diproyeksikan pada ketentuan pelanggaran hukum yang tidak hanya disebabkan karena faktor politik. Namun dalam konteks ini Impeachment diartikan sebagai proses pendakwaan Presiden dan/atau Wakil Presiden di hadapan parlemen atas dugaan pelanggaran hukum yang dilakukan dalam masa jabatan (Sumbu, 2010: 252). Sebaliknya dalam forum previlegiatum (peradilan khusus) merupakan pemberhentian Presiden dan/atau Wakil Presiden di tengah masa jabatannya dilakukan oleh suatu lembaga peradilan yang dibentuk khusus untuk mengadili perihal pemberhentian Presiden dan/atau Wakil Presiden dalam masa jabatannya itu (Saleh dan Mukhlish, 2010: 38).

UUD 1945 yang disahkan oleh PPKI pada tanggal 18 Agustus 1945 pun mengatur mengenai mekanisme yuridis pertanggungjawaban Presiden dalam memegang jabatannya. 
Sebelum UUD 1945 diubah, Presiden dan Wakil Presiden bertanggungjawab secara politis kepada rakyat. Namun perlu dipahami, bahwa prosedur atau mekanisme sistem pertanggungjawaban Presiden dan Wakil Presiden kepada rakyat dilakukan secara tidak langsung melalui MPR. Mekanisme seperti itu pada gilirannya melahirkan anggapan, bahwa sistem pemerintahan Indonesia tidak sepenuhnya menganut presidensial murni. Karena MPR yang memiliki kewenangan memberhentikan Presiden dan Wakil Presiden merupakan lembaga politik yang tugas dan fungsinya mirip dengan parlemen. Bahkan secara konstitusonal jelas sekali MPR memiliki kewenangan mengkonstruksi peraturan hukum tertinggi (UUD 1945 dan Ketetapan MPR) yang bersifat imperatif untuk dilaksanakan.

Sebelum Perubahan UUD 1945. Presiden dan Wakil Presiden dapat diberhentikan MPR melalui alasan-alasan yang sumir sifatnya, yaitu karena pejabat negara tersebut telah melanggar atau menyimpang dari haluan negara yang dibuat, digariskan, dan ditetapkan MPR. Namun haluan negara itu sendiri pengertiannya jangkauannya begitu luas dan terkesan absurd atau kabur, sehingga alasan pemberhentian Presiden dan/atau Wakil Presiden berjalan dramatis dan problematis, sebab lebih bernuansa atau berbau politis. Di dalam UUD 1945 sebelum amandemen, tidak ada syarat maupun mekanisme yang mampu menggambarkan dengan jelas bagaimana memberhentikan Presiden dan Wakil Presiden di tengah ataupun dalam masa jabatannya. Hal ini mengakibatkan dalam pemakzulan Presiden dan Wakil Presiden yang mendominasi adalah proses politik, tidak terlihat proses hukum di dalamnya. Nilai sendiri bagaimana sejarah proses pemberhentian Presiden di Indonesia terjadi dua kali yaitu ketika Presiden Soekarno dan Presiden Abdurahman (Manan, 2000: 19-20). Berdasarkan uraian tersebut dapat kemudian disimpulkan, bahwa sebelum Perubahan UUD 1945, sistem pemerintahan yang dikembangkan dan dipraktikan Indonesia dalam sistem ketatanegaraannya adalah presidensial yang mengandung elemen-elemen/nuansa parlementarisme (quasi), terutama dalam mekanisme pemberhentian Presiden dan Wakil Presiden.

MPR melalui Perubahan UUD 1945 secara progresif telah mengubah corak atau wajah konstitusional Indonesia khususnya mengenai pemberhentian Presiden dan/atau Wakil Presiden. Peneguhan, bahwa sistem pemerintahan Indonesia menganut Presidensial murni dilakukan dengan jalan meninjau, memformulasi, dan mengkonstruksi ulang prosedur atau mekanisme pemberhentian Presiden dan/atau Wakil Presiden melalui Perubahan UUD 1945. Pernyatan di atas sesuai dengan pendapat Asshiddiqie (2007;317), bahwa dalam hal sistem pemerintahan, pasca perubahan UUD 1945 Indonesia menganut sistem pemerintahan presidensil yang lebih murni sifatnya. Adapun dari ciri sistem presidensialisme Indonesia lainnya ialah masa jabatan yang tetap bagi seorang yang menduduki singgasana Presiden dan Wakil Presiden, yakni selama lima tahun. Dengan demikian, berarti bahwa Presiden dan/atau Wakil Presiden tidak mungkin bisa dijatuhkan sewaktu-waktu di tengah jalan oleh lembaga politik, yaitu DPR dengan alasan-alasan politisnya. Namun demikian bukan berarti tidak mungkin bagi Presiden dan/atau Wakil Presiden diberhentikan dalam masa jabatannya. Apalagi Pasal 1 ayat (3) UUD 1945 menegaskan, bahwa Indonesia adalah negara hukum. Dengan demikian, segala perbuatan yang dilakukan harus berdasar dan bersumber pada hukum serta dapat dipertanggungjawabkan secara hukum, termasuk juga Presiden.

Politik hukum UUD 1945 pasca perubahan menganut paradigma baru yang membuka peluang secara terbuka untuk memberhentikan Presiden dan/atau Wakil Presiden dalam masa jabatannya melalui upaya yuridis dan konstitusional misalnya dengan pranata impeachment bilamana memang terbukti melakukan pelanggaran hukum dan pelanggaran lainnya, seperti yang digariskan UUD 1945. Tetapi secara garis besarnya, dalam sistem pemerintahan presidensial, bahwa Presiden dan/atau Wakil Presiden tidak mungkin dijatuhkan dalam masa jabatannya oleh badan politik melalui alasan-alasannya yang berbau atau bermotifkan politis. Prosedur pemakzulan Presiden dan/atau Wakil Presiden bermuatan politis lazimnya hanya terjadi di negara-negara yang menganut dan mengembangkan praktik pemerintahan parlementer. Sebab apabila kita mengacu pada sistem pemerintahan presidensial versi UUD 1945 pasca perubahan, Presiden dan/atau Wakil Presiden hanya mungkin diberhentikan dalam masa jabatannya bila benar-benar terbukti melakukan pelanggaran terhadap UUD 1945. Dengan tersedianya mekanisme konstitusional pemberhentian Presiden dan/atau Wakil Presiden dalam 
UUD 1945, jelas semakin menegaskan, bahwa Indonesia merupakan negara hukum (rechtstaat or rule of law) yang pada prinsipnya memposisikan setiap orang sama kedudukannya di hadapan hukum. Hal demikian berimplikasi pada siapapun yang melakukan pelanggaran hukum (onrechtmatigeaad), entah orang itu adalah rakyat jelata atau sekalipun Presiden haruslah dapat dimintai pertanggungjawabannya atas segala akibat perbuatannya di depan hukum.

Terkait dengan persoalan tersebut dalam Pasal 7A UUD 1945 diungkapkan beberapa alasan konstitusional yang bisa digunakan sebagai senajata pamungkas untuk melengserkan Presiden dan/atau Wakil Presiden dari jabatannya. Dalam Pasal 7A UUD 1945 dinyatakan, bahwa.

"Presiden dan/atau Wakil Presiden dapat diberhentikan dalam masa jabatannya oleh Majelis Permusyawaratan Rakyat atas usul Dewan Perwakilan Rakyat, baik apabila terbukti telah melakukan pelanggaran hukum berupa pengkhianatan terhadap negara, korupsi, penyuapan, tindak pidana berat lainnya, atau perbuatan tercela maupun apabila terbukti tidak lagi memenuhi syarat sebagai Presiden dan/atau Wakil Presiden".

Disusul juga kemudian dengan lahirnya ketentuan Pasal 7B UUD 1945 yang merupakan unsur pendukung bagi terlaksananya mekanisme pemberhentian Presiden dan/atau Wakil Presiden dalam masa jabatannya. Pasal 7 B UUD 1945 berbunyi.

1. Usul pemberhentian Presiden dan/atau Wakil Presiden dapat diajukan oleh Dewan Perwakilan Rakyat kepada Majelis Permusyawaratan Rakyat hanya dengan terlebih dahulu mengajukan permintaan kepada Mahkamah Konstitusi untuk memeriksa, mengadili, dan memutus pendapat Dewan Perwakilan Rakyat, bahwa Presiden dan/atau Wakil Presiden telah melakukan pelanggaran hukum berupa pengkhianatan terhadap negara, korupsi, penyuapan, tindak pidana berat lainnya, atau perbuatan tercela; dan/atau pendapat bahwa Presiden dan/atau Wakil Presiden tidak lagi memenuhi syarat sebagai Presiden dan/atau Wakil Presiden.

2. Pendapat Dewan Perwakilan Rakyat bahwa Presiden dan/atau Wakil Presiden telah melakukan pelanggaran hukum tersebut ataupun telah tidak lagi memenuhi syarat sebagai Presiden dan/atau Wakil Presiden adalah dalam rangka pelaksanaan fungsi pengawasan Dewan Perwakilan Rakyat.

3. Pengajuan permintaan Dewan Perwakilan Rakyat kepada Mahkamah Konstitusi hanya dapat dilakukan dengan dukungan sekurang-kurangnya 2/3 dari jumlah anggota Dewan Perwakilan Rakyat yang hadir dalam sidang paripurna yang dihadiri oleh sekurangkurangnya 2/3 dari jumlah anggota Dewan Perwakilan Rakyat.

4. Mahkamah Konstitusi wajib memeriksa, mengadili, dan memutus dengan seadil-adilnya terhadap pendapat Dewan Perwakilan Rakyat tersebut paling lama sembilan puluh hari setelah permintaan Dewan Perwakilan Rakyat itu diterima oleh Mahkamah Konstitusi.

5. Apabila Mahkamah Konstitusi memutuskan bahwa Presiden dan/atau Wakil Presiden terbukti melakukan pelanggaran hukum berupa pengkhianatan terhadap negara, korupsi, penyuapan, tindak pidana berat lainnya, atau perbuatan tercela; dan/atau terbukti bahwa Presiden dan/atau Wakil Presiden tidak lagi memenuhi syarat sebagai Presiden dan/atau wakil Presiden, Dewan Perwakilan Rakyat menyelenggarakan sidang paripurna untuk meneruskan usul pemberhentian Presiden dan/atau Wakil Presiden kepada Majelis Permusyawaratan Rakyat.

6. Majelis Permusyawaratan Rakyat wajib menyelenggarakan sidang untuk memutuskan usul Dewan Perwakilan Rakyat tersebut paling lambat tiga puluh hari sejak Majelis Permusyawaratan Rakyat menerima usul tersebut.

7. Keputusan Majelis Permusyawaratan Rakyat atas usul pemberhentian Presiden dan/atau Wakil Presiden harus diambil dalam rapat paripurna Majelis Permusyawaratan yang dihadiri oleh sekurang-kurangnya 3/4 dari jumlah anggota dan disetujui oleh sekurang-kurangnya 2/3 dari jumlah anggota yang hadir, setelah Presiden dan/atau Wakil Presiden diberi kesempatan menyampaikan penjelasan dalam rapat paripurna Majelis Permusyawaratan Rakyat. 
Panorama ketatanegaraan dengan nuansa berbeda dapat kita temukan setelah diinjeksikannya Pasal 7A dan 7B UUD 1945 yang merupakan hasil perubahan ketiga dengan maksud lebih memperjelas dan menegaskan kedudukan Presiden dalam sistem pemerintahan presidensial dalam konteks negara hukum (rule of law). Kedudukan MPR dalam pasal tersebut tidak lagi berwenang untuk menjatuhkan ataupun memberhentikan Presiden dan/atau Wakil Presiden secara mandiri andaikata jalur yang ditempuh kedua pejabat tersebut berseberangan dengan haluan yang diatur dan digariskan MPR alias neben.

Mengenai mekanisme dan lembaga negara (state institutional) yang berwenang melaksanakan impeachment Presiden dan/atau Wakil Presiden untuk sekarang ini tidak mungkin dijalankan oleh satu institusi negara saja, melainkan juga melibatkan peran tiga organ negara sekaligus. Lembaga negara yang ikut serta terlibat dan berkecimpung secara langsung dalam proses pemberhentian Presiden dan/atau Wakil Presiden, yaitu DPR, MK, dan juga MPR. Perpaduan kewenangan dari ketiga lembaga negara tersebut dalam mekanisme impeachment Presiden dan/atau Wakil Presiden adalah usaha sadar dan terencana secara yuridis konstitusional dalam rangka untuk tetap mempertahankan, semakin menenguhkan sekaligus juga mengoptimalkan ataupun memaksimalkan mekanisme checks and balances dalam sistem ketatanegaraan Indonesia. Diterapkannya upaya saling mengawasi dan mengimbangi (checks and balances) antar lembaga negara dalam proses pemberhentian Presiden dan/atau Wakil Presiden adalah sebagai jaminan utama pengimpelementasiannya tidak dilaksanakan secara serampangan seperti sebelumnya.

Adapun mekanisme pemakzulan Presiden dan/atau Wakil Presiden diawali dengan lahirnya pendapat DPR yang di dalamnya mengandung muata dugaan atau tuduhan pelanggaran yang dilakukan Presiden dan/atau Wakil Presiden, seperti yang telah digariskan/ditentukan secara limitatif dalam UUD 1945, dan/atau DPR berpendapat, bahwa Presiden dan/atau Wakil Presiden tidak lagi memenuhi syarat sebagai Presiden dan/atau Wakil Presiden. Pendapat DPR tersebut barulah sebatas dugaan yang substansinya lebih didominasi oleh nuansa politis daripada yuridis. Muatan politis begitu pekat menyelimuti di dalamnya, apabila kita meninjaunya kembali dari institusi atau lembaga yang mengusulkan pendapat tersebut. Atmosfir politik sangat kental mewarnai proses pemberhentian Presiden dan/atau Wakil Presiden ketika anggota DPR mencoba menggalang dukungan politik agar memperoleh syarat minimal jumlah suara, yaitu sekurang-kurangnya $2 / 3$ dari jumlah anggota DPR yang hadir dalam sidang paripurna yang dihadiri oleh sekurang-kurangnya 2/3 dari jumlah anggota DPR, sehingga bisa diajukan ke MK. Pendapat DPR tersebut merupakan rangkaian tugas dan wewenangnya dalam rangka menjalankan fungsi pengawasan politik terhadap penyelenggara tugas pemerintahan oleh Presiden dan/atau Wakil Presiden yang perlu diklarifikasi dan verifikasi kembali kebenarannya melalui forum peradilan ketatanegaraan. Impeachment sendiri adalah bentuk pengawasan legislatif yang luar biasa terhadap eksekutif dan merupakan tindakan politik dengan hukuman berhenti dari jabatan dan kemungkinan larangan untuk memegang suatu jabatan (Zoelva, 2011: 9).

DPR merupakan lembaga negara yang merupakan puncak dari perhelatan sekaligus juga menjadi sarang pergulatan politik negara. Dengan demikian, bahwa pendapat DPR yang memuat tuduhan, dkwaan, atau dugaan pelanggaran hukum maupun pelanggaran yang lainnya oleh Presiden dan/atau Wakil Presiden menurut UUD 1945 tidaklah dengan serta merta sebagai putusan yang bersifat final dan mengikat (final and binding). Bahkan secara konstitusional ditentukan, bahwa DPR tidak diperkenankan mengajukan usul pemberhentian Presiden dan/atau Wakil Presiden secara langsung kepada MPR seperti dulu, bilamana sebelumnya tidak didahului oleh adanya permintaaan kepada MK untuk memeriksa, mengadili, dan memutus pendapat DPR tersebut. Hal tersebut sesuai dengan keberadaan MK yang khusus menangani peradilan ketatanegaraan atau peradilan politik (Mahmud, 2009: 273) Dalam situasi dan kondisi yang demikian itu, MK sesuai dengan kewenangannya bertugas menilai objektivitas pendapat DPR tersebut dengan jalan mengujinya (review) kembali melalui forum peradilan ketatanegaraan (previlegiatum). Dalam konteks negara berdasarkan atas hukum, baik rechtsstaat, rule of law maupun negara hukum Pancasila, pemberhentian Presiden sudah 
seharusnya dapat dipertanggungjawabkan secara yuridis konstitusional yang melibatkan lembaga peradilan yang merdeka dan tidak memihak (independent and impartial tribunal), guna membuktikan secara yuridis kebenaran atas perbuatan yang dituduhkan kepada Presiden (Hufron, 2018: 4-5).

Secara konstitusional, MK lah yang berwenang memeriksa, mengadili, dan memutuskan, dengan seadil-adilnya apakah dugaan atau dakwaan DPR dalam bentuk pendapat mengenai pelanggaran hukum maupun pelanggaran lainnya yang disangkakan kepada Presiden dan/atau Wakil Presiden benar-benar terbukti sesuai UUD 1945. Karena tanpa didahului dengan keputusan MK yang menjustifikasi pendapat DPR tersebut, maka upaya politiknya untuk dapat melanjutkan proses imeachment pastilah terhenti secara langsung. Karena dalam perkara ini, putusan MK merupakan titik tolak dan pintu gerbang bagi DPR untuk kemudian meneruskan atau melanjutkan mekanisme impeachment Presiden dan/atau Wakil Presiden ke MPR guna diputuskan secara final dan mengikat (final and binding). Dengan kata lain, bahwa yang sesungguhnya berwenang penuh untuk memutuskan pemberhentian Presiden dan/atau Wakil Presiden bukanlah putusan hukum MK, melainkan tergantung kepada kehendak politis MPR (lihat Pasal 3 ayat 3 UUD 1945). MK secara konstitusional hanya bertugas memastikan dan juga menjamin, bahwa pendapat DPR menyangkut pelanggaran hukum atau larangan lainnya yang disangkakan kepada Presiden dan/atau Wakil Presiden sudah sesuai dengan prinsip yang digariskan dalam ketentuan UUD 1945.

Setelah lahirnya keputusan MK yang menguatkan secara yuridis pendapat DPR mengenai dugaan pelanggaran oleh Presiden dan/atau Wakil Presiden berdasarkan UUD 1945. Baru kemudian DPR menindaklanjutinya kembali dengan jalan menyelenggarakan sidang paripurna untuk meneruskan usul pemberhentian Presiden dan/atau Wakil Presiden kepada MPR. Setelah menerima usul DPR tersebut, MPR mempunyai kewajiban untuk menyelenggarakan rapat paripurna guna sesegera mungkin memutuskan secara final dan mengikat (final dan binding) usul pemberhentian Presiden dan/atau Wakil Presiden. Bahkan, MPR secara konstitusional diberikan limit atau batasan waktu untuk memutuskan kasus tersebut, yakni paling lambat 30 (tiga puluh) hari sejak MPR menerima usul DPR tersebut. Adanya tenggang waktu bagi MPR untuk segera memutuskan pemberhentian Presiden dan/atau Wakil Presiden dimaksudkan untuk menjaga stabilitas politik negara. Jangan sampai proses pemberhentian Presiden dan/atau Wakil Presiden berlarut-larut ataupun berkepanjangan, karena kemungkinan besar bisa menganggu stabilitas politik nasional. Keputusan MPR atas usul DPR tentang pelanggaran Presiden dan/atau Wakil Presiden berdasarkan UUD 1945 harus diambil dalam rapat paripurna, bukan lagi melalui sidang Istimewa MPR seperti sebelum UUD 1945 diubah. Keputusan MPR mengenai pemakzulan Presiden dan/atau Wakil Presiden baru bisa dinyatakan sah apabila dihadiri oleh sekurang-kurangnya 3/4 dari jumlah keseluruhan anggota MPR dan disetujui oleh sekurang-kurangnya 2/3 dari jumlah anggota MPR yang hadir dalam rapat paripurna. Namun untuk keputusan MPR mengenai masalah tersebut baru dapat diambil setelah terlebih dahulu memberikan ruang atau kesempatan bagi Presiden dan/atau Wakil Presiden untuk menyampaikan penjelasan dalam Rapat Paripurna MPR.

Dengan demikian, bahwa proses pemberhentian Presiden dan/atau Wakil Presiden dimulai dari DPR sebagai pemohon tunggal yang oleh UUD 1945 satu-satunya diberikan kedudukan hukum (legal standing) untuk mengajukan permintaan dalam bentuk pendapat politik ke MK untuk diperiksa, diadili, dan diputuskan dengan seadil-adilnya apakah dakwan/dugaan pelanggaran oleh Presiden dan/atau Wakil Presiden benar-benar terbukti sesuai UUD 1945. Apabila pendapat DPR menyangkut dugaan atau dakwaaan pelanggaran Presiden dan/atau Wakil Presiden tidak terbukti di MK, maka prosesnya tidak bisa dilanjutkan lagi. Sedangkan bilamana putusan MK membenarkan pendapat DPR, bahwa Presiden melakukan pelanggaran menurut UUD 1945, maka proses tersebut akan dilanjutkan ke MPR untuk diputuskan secara final dan mengikat (final and binding). Jadi kesimpulan sederhananya mengenai proses impeachment Presiden dan Wakil Pesiden diawali dari adanya pendapat lembaga politik, yaitu DPR, yang kemudian mengajukan permintaan atau permohonan ke lembaga peradilan ketatanegaraan, yakni MK dan bilamana benar-benar terbukti diajukan ke lembaga politik lagi, yaitu MPR untuk selanjutnya diputuskan secara final. 
Menurut Mahmud (2007: 139), bahwa model pemberhentian Presiden Indonesia menganut sistem campuran antara model Impeachment dan model forum previlegiatum yaitu proses penjatuhan Presiden dimulai dari penilaian dan keputusan politik di DPR RI (impeachment) kemudian dilanjutkan ke pemeriksaan dan putusan hukum oleh MK (forum privelegiatum) lalu dikembalikan lagi ke prosedur impeachment (DPR meneruskan ke MPR) untuk diputuskan secara politik apakah putusan MK itu perlu ditindaklanjuti dengan pemberhentian Presiden ataukah tidak. Perlu di pahami, bahwa lembaga impeachment ini hanyalah sarana untuk memungkinkan dilakukannya pemberhentian terhadap pejabat publik, tetapi hasilnya tergantung proses pembuktian hukum dan proses politik yang menentukan kemungkinan dilakukan atau tidaknya pemberhentian itu (Abdul Rasyid Thalib, 2006: 463).

\section{Metode}

Metode yang digunakan dalam penelitian ini adalah penelitian kepustakaan. Penelitian ini dilakukan dengan cara mengumpulkan berbagai bahan yang berasal dari berbagai buku, artikel, jurnal, makalah, koran, serta bahan-bahan lainnya yang berkaitan dengan masalah presidensialisme dan problematika mekanisme impeachment Presiden dan/atau Wakil Presiden berdasarkan UUD 1945 yang kemudian dinarasikan kembali dalam bentuk deskriptif yang dianalisis dengan teknik pengolahan data secara kualitatif, yakni dengan mengkomparasikan data yang diperoleh di lapangan dengan data kepustakaan. Kemudian dari hasil pengolahan ini disajikan dengan analisis deskriptif, disusun secara logis dan sistematis, setelah data dianalisis maka diperoleh suatu simpulan umum sehubungan dengan permasalahan dalam penulisan ini dan pelaksanaanya dalam praktik.

\section{Hasil dan pembahasan}

Setelah UUD 1945 diubah, MPR melalui kewenangannya juga membentuk lembaga negara baru bernama MK yang berkewajiban memutuskan pendapat DPR mengenai dugaan pelanggaran Presiden dan/atau Wakil Presiden berdasarkan UUD 1945. Mekanisme pemberhentian Presiden dan/atau Wakil Presiden yang diformalisasikan dalam Pasal 7A dan 7B UUD 1945 merupakan perubahan yang bersifat radikal, sehingga berpengaruh signifikan terhadap sistem pemerintahan yang dianut Indonesia.

Apabila dikaji dari segi bentuk pertanggungjawabannya saja, maka UUD 1945 pra perubahan lebih bersinggungan dengan ranah politis. Sedangkan setelah Perubahan UUD 1945, kadar politisnya berusaha dikurangi dan diminimalisir seraya lebih menonjolkan sisi yuridisnya. Mengingar terdapat perbedaan tajam antara bentuk pertanggungjawaban secara politis dengan yuridis. Bahwa sistem pertangungjawaban secara yuridis adalah bersifat perorangan (individual), sehingga dalam Pasal 7A dijumpai kata "atau". Sehingga yang nantinya dapat dimintai pertanggungjawaban atas pelanggaran hukum adalah Presiden "atau" Wakil Presiden saja. bukan kedua pejabat itu sekaligus seperti yang lazimnya berlaku dalam mekanisme pertanggungjawaban politis. Namun hasil Perubahan UUD 1945 rupanya juga membuka peluang untuk meminta pertanggungjawaban Presiden dan Wakil Presiden secara bersamaan bila pelanggaran dilakukan kedua pejabat tersebut berbarengan.

Problematika pemakzulan atau pemberhentian Presiden dan/atau Wakil Presiden yang muncul dari Pasal 7A dan 7B adalah terletak pada lembaga yang berwenang memutuskan secara final terhadap pendapat DPR mengenai dugaan pelanggaran Presiden dan/atau Wakil Presiden. Apabila kita berpedoman pada ketentuan Pasal 3 Ayat (3), Pasal 7A, Pasal 7B, dan Pasal 24C Ayat (2) UUD 1945, maka lembaga yang berwenang untuk memberhentikan Presiden dan/atau Wakil Presiden secara konstitusional adalah MPR. Namun supaya MPR dapat mengoperasionalkan kewenangannya itu, perlulah terlebih dahulu mendapatkan keputusan hukum dari MK. Jadi fungsi dan wewenang MPR tersebut tidak mungkin bisa diimplementasikan apabila MK belum memutuskan pendapat DPR mengenai dakwaan/dugaan pelanggaran oleh Presiden dan/atau Wakil Presiden terbukti sesuai UUD 1945. Dengan demikian, kewenangan checks and balances dikembalikan kepada lembaga ini (Budiardjo,2008: 291) 
Tetapi sangat disayangkan sekali bahwa mengapa setelah ada putusan hukum dari MK, mekanisme pemakzulan Presiden dan/atau Wakil Presiden kembali lagi kepada proses politis, yaitu melalui syarat-syarat qourum (jumlah minimal), seperti yang tertuang secara eksplisit dalam Pasal 7B ayat (7) UUD 1945? Pertanyaan lain yang juga muncul adalah mengapa Presiden dan/atau Wakil Presiden yang menurut pendapat DPR terbukti bersalah sesuai dengan putusan MK tetapi masih diberi kesempatan lagi untuk menyampaikan penjelasan di depan Rapat Paripurna MPR?

Penulis paham, bahwa pangkal dari segala problematika yang timbul dalam mekanisme pemakzulan Presiden dan/atau Wakil Presiden adalah terletak pada kekuatan (power) putusan MK yang ditentukan tidak mengikat dan final untuk memberhentikan Presiden dan/atau Wakil Presiden, meskipun pejabat tersebut melalui pendapat DPR telah terbukti melanggar larangan yang tertuang dalam Pasal 7A UUD 1945. Dengan kata lain, bahwa kekuatan putusan MK yang secara konstitusional telah menjusifikasi atau membenarkan pendapat DPR mengenai dugaan pelanggaran Presiden dan/atau Wakil Presiden berdasarkan UUD 1945, tetapi faktanya nasib putusan tersebut masih digantungkan lagi pada dukugan politis MPR. Akan lebih ironis lagi apabila kita mencermati ketentuan UUD 1945, bahwa MPR baru dapat mengambil putusan setelah memberikan kesempatan kepada Presiden dan/atau Wakil Presiden untuk menyampaikan penjelasan dalam Rapat Paripurna MPR. Adapun yang kemudian menjadi pertanyaan, apakah putusan MK dengan penjelasan yang dikemukakan Presiden dan/atau Wakil Presiden bernilai atau berkekuatan sama di depan Rapat Raripurna MPR?

Tampaknya pendapat demikian tersebut benar adanya. Bahwa penjelasan Presiden dan/atau Wakil Presiden bernilai sebanding dengan putusan MK di depan Rapat Paripurna MPR. Karena terdapat dua opsi atau pilihan bagi MPR sebagai dasar pertimbangan dalam memutuskan pendapat DPR mengenai hal tersebut. Pertama, MPR memutuskan dengan mengacu dan berpedoman pada putusan MK, sehingga putusan MPR dengan MK selaras dan sehaluan. Kedua, MPR mengambil putusan dengan berdasarkan pada penjelasan yang disampaikan Presiden dan/atau Wakil Presiden dalam rapat paripurna. Bertitik tolak dari dua alternatif yang dimilikinya itu, MPR kemudian mengambil keputusan apakah akan mengikuti salah satu dari dua opsi tersebut semuanya tercermin kembali pada tercapai atau tidaknya jumlah suara yang diperlukan, seperti yang dipersyaratkan UUD 1945. Bahkan secara politis tidak tertutup peluang, bahwa MPR bisa mengambil putusan di luar dua pilihan tersebut, yakni dengan pertimbangannya sendiri.

Dalam pada itu, pertanyaan berikutnya yang muncul adalah peluang yang diberikan UUD 1945 kepada Presiden dan/atau Wakil Presiden untuk menyampaikan penjelasan dalam Rapat Paripurna MPR apakah sudah sesuai dengan konsep negara hukum (rechtstaat or rule of law) yang dianut Indonesia (Pasal 1 ayat (3) UUD 1945)? Penjelasan apakah yang hendak disampaikan Presidn dan/atau Wakil Presiden dalam Rapat Paripurna MPR, padahal MK sesuai konstitusi telah memutuskan pendapat DPR, bahwa Presiden dan/atau Wakil Presiden terbukti melanggar pantangan sesuai dengan ketentuan Pasal 7A UUD 1945? Apakah tidak lebih baik, bilamana penjelasan Presiden dan/atau Wakil Presiden tersebut disampaikan pada MK saat menggelar persidangan? Terlebih lagi, bahwa kewajiban MK untuk kasus ini adalah memeriksa, mengadili dan memutuskan dengan seadil-adilnya pendapat DPR berupa dakwaan/dugaan penyimpangan Presiden dan/atau Wakil Presiden menurut UUD 1945. Dengan demikian tampak jelas, bahwa ketentuan Pasal 7B ayat (7) UUD 1945 tidak selaras, bahkan bertolak belakang dengan prinsip negara hukum yang demokratis. Sebab pengaturan yang demikian itu, justru mengingkari prinsip utama dalam negara hukum, bahwa setiap orang dianggap sama kedudukannya di depan hukum (equality before of the law) (Wahjono,1992: 131), walaupun yang diduga melakukan perbuatan melanggar atau melawan hukum tersebut adalah seorang manusia yang kebetulan pada waktu itu dipercaya oleh rakyat untuk menduduki jabatan sebagai Presiden dan/atau Wakil Presiden. Mekanisme seperti itu sungguh tidak fair karena Presiden dan/atau Wakil Presiden yang sudah terbukti bersalah berdasarkan pendaapat DPR yang sudah diteguhkan dan dikuatkan lagi dengan putusan MK melalui forum previlegiatum faktanya masih diberikan kesempatan untuk menyampaikan penjelasan dalam Rapat Paripurna MPR. 
Berpijak pada penjelasan di atas, persoalan ketatanegaraan justru timbul kemudian, yaitu apabila kita menyatakan Indonesia sebagai negara hukum (Pasal 1 ayat (3) UUD 1945). Karena dalam negara hukum, semestinya politik lebih inferior kedudukannya bila dibandingkan dengan hukum. Lebih jelas lagi, bahwa permasalahan ketatanegaraan yang timbul dan meliputi mekanisme pemberhentian Presiden dan/atau Wakil Presiden ditinjau dari sudut negara hukum adalah tentang putusan MK yang tidaklah bersifat final dan mengikat. Karena setelah melalui tahap forum peradilan atau previlegiatum tersebut, proses pemberhentian Presiden dan/atau Wakil Presiden masih perlu dikonstatir kembali secara politik oleh DPR untuk selanjutnya diajukan dalam Rapat Paripurna MPR guna diputuskan secara final dan mengikat sesuai dengan ketentuan Pasal 3 ayat (3) UUD 945. Berarti putusan MK tersebut hanya dijadikan bahan usulan kepada MPR untuk diselesaikan atau diputuskan secara politis. Menyangkut diberhentikan atau tidaknya Presiden dan/atau Wakil Presiden adalah sangat bergantung pada kehendak politis MPR yang tercermin pada jumlah suara yang harus dipenuhi untuk bisa mengambil keputusan secara konstitusional. Dengan demikian, maka kewenangan pemberhentian Presiden dan/atau Wakil Presiden sepenuhnya berada di tangan lembaga politik MPR, bukan pada MK yang merupakan lembaga peradilan.

Dari pemaparan tersebut di atas, kesimpulan yang bisa diperoleh adalah putusan MK menurut Pasal 24C ayat (2) UUD 1945 bukanlah bersifat final dan mengikat untuk dapat memberhentikan Presiden dan/atau Wakil Presiden, karena MPR melalui kewenangannya tersebut dapat saja menganulir atau menolaknya. Bahkan dengan pemberian kesempatan ataupun peluang yang berulang kali kepada Presiden dan/atau Wakil Presiden untuk menyampaikan penjelasan baik pada saat persidangan di MK maupun dalam Rapat Paripurna MPR merupakan cacat konstitusional bagi dunia peradilan di bumi Indonesia. Karena penjelasan Presiden dan/atau Wakil Presiden telah ditolak MK, sekaligus mengukuhkan dan membenarkan pendapat DPR, bahwa Presiden dan/atau Wakil Presiden telah melanggar pantangan konstitusional yang tertuang secara eksplisit dalam UUD 1945. Dengan demikian, mekanisme pemberhentian Presiden dan/atau Wakil Presiden secara tidak langsung telah membuktikan, bahwa prosedur hukum kita tidak sepenuhnya meletakan prinsip persamaan kedudukan di hadapan hukum.

Problematika besar pun menanti sistem ketatanegaraan Indonesia apabila dikemudian hari terjadi silang keputusan antara MPR dengan MK. Misalkan saja MK memutuskan, bahwa pendapat DPR mengenai dugaan pelanggaran yang dilakukan Presiden dan/atau Wakil Presiden adalah terbukti benar, yang berarti secara tidak langsung pejabat negara tersebut sesungguhnya bersalah atas kasus yang dituduhkan oleh DPR kepadanya sesuai dengan ketentuan Pasal 7A UUD 1945. Namun putusan MK tersebut bisa saja dianulir atau ditolak MPR, karena mimimnya dukungan politis dari mayoritas anggotanya untuk dapat memberhentikan Presiden dan/atau Wakil Presiden dari jabatannya. Putusan MPR yang bertolak belakang dengan putusan MK adalah sungguh bertentangan dengan prinsip dasar negara hukum Indonesia (rule of law or rechtstaat) yang menghendaki ditegakannya konsep supremasi hukum (supremacy of law), atas politik. Namun bilamana Presiden dan/atau Wakil Presiden ternyata tidak diberhentikan oleh MPR sesuai dengan keputusan MK, berarti politiklah yang determinan atas hukum. Alur politik hukum seperti inilah yang mendasari kekeliruan (baik disengaja atau tidak) sebagian anggota MPR dalam memahami mekanisme checks and balances yang hendak diterapkan pada UUD 1945.

Menurut argumentasi penulis, problematikanya adalah berdasar dan bersumber pada cacat konstitusional, yaitu proses yang memang sejak semula tidak benar dalam ketentuan Pasal 7A dan 7B UUD 1945. Sehingga, untuk kedepannya apabila terbuka peluang lagi untuk mengadakan perubahan lanjutan terhadap UUD 1945, maka perlulah dipikirkan kembali untuk merekonstruksi dan merevisi ulang lagi ketentuan yang mengatur mekanisme pemberhentian Presiden dan/atau Wakil Presiden yang sungguh-sungguh sesuai dengan konsep negara yang menganut dan memegang teguh prinsip-prinsip hukum yang demokratis (democratische rechtstaat). 


\section{Simpulan dan saran}

Berdasarkan hasil pembahasan di atas, maka dapat disimpulkan sebagai berikut. Terdapat hubungan yang signifikan antara sistem pemerintahan Presidesialisme Indonesia dengan mekanisme impeachment Presiden dan/atau Wakil Presiden dalam UUD 1945 baik sebelum maupun sesudah perubahan. Di mana mekanisme impeachment Presiden yang dipraktikan MPR sebelum Perubahan UUD 1945 yang di dalamnya hanya melibatkan lembaga politik dengan alasan-alasan politisnya secara teoritis dinilai lebih mencerminkan sistem pemerintahan parlementerisme ketimbang sistem pemerintahan presidensial. Sedangkan sekarang setelah Perubahan UUD 1945, impeachment tidak hanya melibatkan lembaga politik semata, melainkan sudah menyertakan institusi peradilan, yaitu MK, sehingga dalam konteks ini hukum sudah berperan dan berfungsi mengontrol jalannya sistem politik Indonesia. Dengan demikian, mekanisme impeachment Presiden dan/Wakil Presiden pasca Perubahan UUD 1945 sudah sesuai dengan sistem pemerintahan preidensial. Problematika yang dijumpai dalam mekanisme impeachment Presiden dan/atau Wakil Presiden Berdasarkan UUD 1945 (Perspektif Pergulatan Politik dan Hukum) yaitu terletak pada proses dan lembaga yang berwenang memakzulkan Presiden dan/atau Wakil Presiden. Di mana putusan MK tidak lah bersifat dan mengikat dalam kasus ini. Mengingat kewenangan memberhentikan Presiden dan/atau Wakil Presiden adalah hak prerogatif MPR. Sehingga putusan hukum MK bisa dianulir secara politik oleh MPR. Persoalan lainnya adalah pemberian kesempatan kepada Presiden dan/atau Wakil Presiden untuk menyampaikan pendapat dalam Rapat Paripurna MPR, padahal sudah ada putusan MK yang membenarkan pendapat DPR mengenai pelanggarannya menurut UUD 1945. Di tambah lagi adanya kemungkinan pertentangan keputusan antara MK dengan MPR yang bisa menurunkan supremasi hukum atas politik. Bahwa pergulatan politik dan hukum dalam mekanisme pemberhentian Presiden dan/atau Wakil Presiden sebagaimana diatur dalam UUD 1945 tidak meletakan prinsip supremasi hukum atas politik. Mengingat putusan konstitusional MK atas pendapat DPR tersebut tidaklah bersifat final dan mengikat (final dan binding), melainkan masih terbuka kemungkinan untuk dianulir kembali oleh MPR melalui mekanisme politik yang disedikan UUD 1945. Dengan demikian, seola-olah proses tersebut menempatkan putusan politik lebih tinggi (supreme) dari putusan lembaga peradilan, sehingga tidak lah sesuai dengan negara hukum Indonesia yang dicita-citakan selama ini oleh the founding fathe.

Berdasarkan simpulan penelitian dapat disampaikan beberapa saran sebagai berikut. Supaya mekanisme pemberhentian Presiden dan/atau Waki Presiden sesuai dengan prinsip negara hukum, sebaiknya MPR dalam memutuskan hal tersebut tidak berbeda dengan putusan MK. Mengingat MK adalah lembaga hukum, sedangkan MPR merupakan institusi politik. Dengan keselarasan putusan MPR dengan MK, maka pergulatan antara politik dan hukum dimenangkan oleh hukum sehingga supremasi hukum atas politik bisa terwujud. Bukan malah sebaliknya, politik determinan atas hukum. Bilamana terbuka peluang Perubahan UUD 1945 kembali, maka sebaiknya MPR segera mengkonstruksi dan membenahi mekanisme pemakzulan Presiden dan/atau Wakil Presiden agar lebih sesuai lagi dengan prinsip yang berlaku di negara hukum, di mana hukumlah menjadi panglima, bukan politik.

\section{Daftar Rujukan}

Ambardi, K. 2009. Mengungkap Politik Kartel: Studi Tentang Kepartaian di Indonesia Era Reformasi. Jakarta: Kepustakaan Populer Gramedia.

Asshiddiqie, J. 2007. Pokok-Pokok Hukum Tata Negara Indonesia Pasca Reformasi. Jakarta. Buana Ilmu Populer.

Bagir, M. 2000. Teori dan Politik Konstitusi. Jakarta: Direktorat Jenderal Pendidikan Tinggi Departemen Pendidikan Nasional,

Budiardjo, M. 2008. Dasar-Dasar Ilmu Politik. Cet.XXX. Jakarta: PT. Gramedia Pustaka Utama.

Fatkhurohman dan Sjuhad, M. 2010. Memahami Pemberhentian Presiden (Impeachment) Di Indonesia (Studi Perbandingan Pemberhentian Presiden Soekarno dan Presiden Abdurrahman Wahid). Puskasi FH Universitas Widyagama Malang. Jurnal Konstitusi, Vol. 3(1). 
Hufron. 2018. Pemberhentian Presiden di Indonesia antara Teori dan Praktik. Yogyakarta: LasBang Pressindo.

Isra, S. 2010. Pergeseran Fungsi Kekuasaan Legislasi Menguatnya Model Legislasi Parlementer Dalam Sistem Presidensial Indonesia. Jakarta: PT. Raja Grafindo Persada.

Lijphart, A. 1994. Sistem Pemerintahan Parlementer dan Presidensial. Jakarta: PT. Raja Grafindo Persada.

Mahfud, M.D. 2007. Perdebatan Hukum Tata Negara Pasca Amandemen Konstitusi. Jakarta; LP3ES

Mahfud, M.D. 2009. Konstitusi Dan Hukum dalam Kontroversi Isu. Cet. I. Jakarta: PT. RajaGrafindo Persada.

Mulyosudarmo, S. 1997. Peralihan Kekuaaan: Kajian Teoritis Dan Yuridis Terhadap Pidato Nawaksara. Jakarta PT. Gramedia Pustaka Utama.

Ni'mah, M. D. 2012. Analisis Yuridis Impeachment Presiden dan/atau Wakil Presiden Dalam Sejarah Ketatanegaraan Indonesia. Fakultas Hukum Universitas 17 Agustus 1945 Surabaya. Jurnal Ilmu Hukum, Vol. 8(15): 48-59.

Saleh, M dan Mukhlish. 2010. Impeachment Presiden dan/atau Wakil Presiden (Sebuah Tinjauan Konstitusional). Surabaya: Bina Ilmu Offset.

Sapuan. 2010. Impeachment Presiden. Purwokerto: STAIN Pres.

Soimin. 2009. Impeachment Presiden dan Wakil Presiden di Indonesia. Yogyakarta: UII Press.

Sumbu, T 2010. Kamus Umum, Politik dan Hukum. Jakarta; Permata Aksara.

Thalib, A. R. 2006. Wewenang Mahkamah Konstitusi dan Implikasinya dalam Sistem Ketatanegaraan Republik Indonesia. Bandung: Citra Aditya Bakti.

Wahjono, Padmo dalam Oesman, Oetojo dan Alfian. 1992. Pancasila Sebagai Ideologi. Dalam Berbagai Bidang Kehidupan Bermasyarakat, Berbangsa, dan Bernegara. Cet. III. Jakarta: Perum Percetakan Negara RI

Zoelva, H. 2011. Impeachment Presiden. Jakarta: Konstitusi Press.

Zoelva, H. 2011. Pemakzulan Presiden di Indonesia. Jakarta: Sinar Grafika. 